\title{
Nutritional quality of vegetable and seed from different accessions of Amaranthus in South Africa"
}

\author{
AP Mnkeni ${ }^{1 *}$, P Masika $^{1}$ and M Maphaha ${ }^{2}$ \\ ${ }^{1}$ Agricultural Rural Development Research Institute, University of Fort Hare, Private Bag X1314, Alice 5700, South Africa \\ ${ }^{2}$ Department of Agronomy, University of Fort Hare, Private Bag X1314, Alice 5700, South Africa
}

\begin{abstract}
Amaranthus vegetable and seed are highly nutritious, but in many parts of South Africa they are hardly utilised as food. Assessment of five accessions of Amaranthus available in South Africa was carried out to select the best accession for vegetable and seed. Seeds were planted in pots in a glass house and leaves and seed were harvested. Leaves were analysed for ascorbic acid, crude protein, nitrate and minerals. Seeds were analysed for protein, fat and minerals.

Ascorbic acid content in the leaves varied between 630 and $496 \mathrm{mg} / 100 \mathrm{~g}$. V2 contained significantly higher amount of nitrates (1 $474 \mathrm{mg} / 100 \mathrm{~g})$ while VOP and AMA17 had the lowest $(729 \mathrm{mg} / 100 \mathrm{~g})$. AMA 17 leaves had the highest concentrations for all the minerals that were determined in leaves. The seeds of AMA17 contained significantly higher amounts of manganese, calcium and zinc than the seeds from all other accessions and it is therefore most recommended, especially in view of the more favourable health aspects thereof. VOP seed would probably be more acceptable to the local population as food because of the cream colour compared to the black colour of the other accessions.
\end{abstract}

Keywords: Amaranthus accessions, nitrates, nutrient content, manganese, calcium, zinc

\section{Introduction}

The genus Amaranthus has received considerable attention in many countries because of the high nutritional value of some species that are important sources of food, either as vegetable or grain. The leaves contain 17.5 to $38.3 \%$ dry matter as protein of which 5\% is lysine (Oliveira and De Carvallo, 1975). Vitamin A and $\mathrm{C}$ are also present in significant levels. One hundred grams of the vegetable material cooked without oil can contribute $45 \%$ of daily Vitamin A requirement (Mulokozi et al., 2004 as quoted by FAO 2004). Compared to spinach, Amaranthus contains three times more vitamin $\mathrm{C}$, calcium and niacin. Compared to lettuce, Amaranthus contains 18 times more vitamin A, 13 times more vitamin C, 20 times more calcium and 7 times more iron (Guillet, 2004). A study by Allemann et al. (1996) showed that amaranth has the potential to be a valuable source of nutrition in areas in Africa with hot, dry climates. The crop can grow on marginal lands and when it gets well established it can withstand acute drought conditions.

The grain amaranth is a pseudo-cereal with unique nutritional and agronomic attributes. The cooked grain is $90 \%$ digestible and because of its ease of digestion it has traditionally been given to those recovering from illness or fasting period (Morales et al., 1988). Amaranth seed is high in protein (8.8 to 19.5\%) which is in turn high in lysine and sulphur-containing amino acids that are not frequently found in appreciable amounts in plant proteins (Centeotl, 2002). The fibre content of Amaranth seeds is three times that of wheat and its iron content is five times more than wheat. It contains two times more calcium than milk. Using amaranth in combination with wheat, maize or brown rice resulted in a complete protein as high in food value as fish, red meat and poultry. The oil from the seeds (5 to $10 \%$ ) is

\footnotetext{
Revised version. Originally presented at the International Symposium on the Nutritional Value and Water Use of Indigenous Crops for Improved Livelihoods held on 19 and 20 September 2006 at the University of Pretoria in Pretoria, South Africa.

* To whom all correspondence should be addressed.

용 +2740 602-2096; fax: +2740 653-1730;

e-mail: amnkeni@ufh.ac.za
}

predominantly unsaturated and is high in linoleic acid and rich in squalene (Dhellot et al., 2006).

In spite of all these amazing good nutritional qualities Amaranthus seed is not widely consumed in South Africa. The vegetable is consumed to some extent in the northern parts of the country. In the Eastern Cape the leaves are mainly eaten by women because the Xhosa people believe that men who eat Amaranthus would become effeminate (Peter \& Ngwandla, 2001). There is also a belief that eating purplish or reddish colour leaves, like those of some accessions of Amaranthus, would make one insane. Another reason why the crop is not used is probably due to lack of knowledge on the potential of Amaranthus as a source of a high level of nutrients. Previous work on Amaranthus at the University of Fort Hare was conducted in the department of Agronomy (Maphaha, personal communication). The work involved the collection of more than 100 accessions of Amaranthus and their evaluation on agronomic aspects, including yield and leaf area. Peter and Ngwadla (2001) evaluated 8 of the accessions as vegetable for taste and acceptability in two villages in the Eastern Cape and found that it was quite acceptable. No work has been done on the Amaranthus seed as food in this area, however. It is therefore important to increase awareness of the exceptional nutritional qualities of the vegetable as well as the seeds of Amaranthus. Information on the nutritional quality of the different accessions is necessary as it has been shown that protein content can vary between 17 and 38\% (Oliveira and Carvallo, 1975) and the contents of minerals such as iron can also vary, depending on variety. Such information is vital in formulating an appropriate package for introducing this crop in the rural areas. Such a package should also include domestic processing and preparation of the food, which is often an area left out of food crop development.

The presence of inherent anti-nutritional components such as nitrates in Amaranthus has been reported (Aletor and Adeogun, 1995). The significance of nitrates in human health derives from the fact that exposure to large amounts of nitrates can lead to formation of carcinogenic nitrosamines and gastric cancer (Mirvish, 1983). Nitrates can also interact with haemoglobin to affect the oxygen transport mechanism giving rise to a condition 
known as methaemoglobinaemia (blue baby syndrome). High levels of nitrate intake can be a problem for individuals suffering from anaemia because of their lower baseline oxygen carrying capacity and therefore making them more susceptible to methaemoglobinaemia (McKnight et al., 1999). This has led some governments to introduce official limits for nitrates in certain types of vegetables, paralleling horticultural adaptations leading to a decrease of nitrate content (Grijspaardt-Vink, 1994). The European commission in 1997 set an Acceptable Daily Intake (ADI) for nitrate ion at $3.65 \mathrm{mg} / \mathrm{kg}$ body weight. It is therefore of importance to know the levels of nitrate in the accessions of Amaranthus which are available in this area and be able to recommend accessions with low levels of nitrate.

With the above in mind the main objective of the research was to assess the quality of selected accessions of Amaranthus available in the Eastern Cape in South Africa. Specific objectives were:

- To determine the nutrient content of vegetable and seed from the selected accessions of Amaranthus

- To determine the nitrate content of the vegetable in selected accessions of Amaranthus.

\section{Materials and methods}

Amaranthus seeds were obtained from the Department of Agronomy at the University of Fort Hare and the ARC-Institute of Vegetable and Ornamental Plants in Pretoria (ARC-VOPI). At Fort Hare the seeds were from a collection of more than a hundred accessions that were collected from the wild in the Eastern Cape. Trials were carried out to select the best accessions based on yield of seed, leaf area, leaf colour and taste of the vegetable. From these trials four accessions were selected, viz. AMA 5, AMA17, AMA 18 and V2. The seeds from these four accessions are black or dark purple. One sample of seeds that are cream in colour was obtained from the ARC-VOPI and was conveniently labelled as VOP.

The five accessions were germinated on seed trays in a glass house on hydromix growing medium. Seven days after germination the seedlings were irrigated with a nutrient solution twice a week and transplanted into pots $22 \mathrm{~d}$ after germination. The pots contained $5 \mathrm{~kg}$ of soil. Before transplanting fertiliser was applied to each pot at a rate of $700 \mathrm{~kg} / \mathrm{ha}$ of 2:3:4 (30), following recommendation by Allemann et al. (1996). The soil was moistened to $20 \%(\mathrm{v} / \mathrm{v})$ and allowed to equilibrate before transplanting. Two seedlings were planted in each pot. The experimental design was a completely randomised block design replicated 3 times. Each replicate had 4 pots. Harvesting was done $20 \mathrm{~d}$ after transplanting by cutting the entire plant at $20 \mathrm{~cm}$ above the ground, with the exception of AMA 17 which was too short and thus was cut at $10 \mathrm{~cm}$ above the ground. The plants were left to re-grow. Two weeks after cutting, a nitrogen fertiliser (LAN) topdressing was applied at a rate of $150 \mathrm{~kg} / \mathrm{ha}$. The plants were left to grow to maturity and the seeds were harvested. Harvesting was done $115 \mathrm{~d}$ after the date of planting, except for the accession AMA 17 which was ready for harvesting only after $156 \mathrm{~d}$.

After harvesting the vegetables, a portion of the fresh material was analysed for ascorbic acid and moisture content while the rest was dried in an oven at $60^{\circ} \mathrm{C}$ to constant weight. The dried material was ground and stored in plastic bags at room temperature and later analysed for nitrate, crude protein, and mineral content. Ascorbic acid content was determined by the method described by Tomohiro (1990) by titrating with 2, 6dichlorophenolindophenol. Total nitrogen was determined by a dry combustion method using a LECO TRUSPEC C/N auto- analyser. The factor 6.25 was used to convert the nitrogen to crude protein. Nitrate determination was done according to the method described by the International Institute of Tropical Agriculture (IITA, 1979). For mineral analysis the samples were digested according to the method of Okalebo et al. (2002). The digest was analysed for minerals using atomic absorption spectrophotometry. Minerals analysed for were iron, calcium, phosphorus, magnesium, manganese, zinc, sodium and potassium. The seeds were also analysed for crude protein, fat and the minerals listed above.

The data obtained were subjected to analysis of variance using MSTAT C statistical package (Freed et al., 1990) and mean separation was done using the least significant difference (LSD) method at the 0.05 level of significance.

\section{Results and discussion}

\section{Nutrient content of the vegetable Amaranth}

Vitamin C contents of the five accessions studied, are shown in Table 1 . The levels of the vitamin varied between $496.5 \mathrm{mg} / 100 \mathrm{~g}$ in AMA17 and $630.9 \mathrm{mg} / 100 \mathrm{~g}$ in AMA5. The amount of vitamin $\mathrm{C}$ in the different accessions differed significantly, with AMA5 having the highest amount and AMA18 and AMA17 having the lowest amounts. The values obtained in this study are comparable with values from other green leafy vegetables (Mathooko and Imungi, 1994; FAO, 1995). Mziray et al. (2001) reported values ranging from 455 to $535 \mathrm{mg} / 100 \mathrm{~g}$ in a single variety of Amaranthus planted at different locations in Dar es Salaam.

There were significant differences $(p<0.05)$ in crude protein content between the vegetables from the different accessions (Table 1). The protein content varied between 25.79 in AMA18 and $31.21 \mathrm{~g} / 100 \mathrm{~g}$ in AMA 17. The values obtained, compare favourably with values reported in literature. Wesche-Ebeling et al. (1995) reported crude protein values ranging from 22.8 to $27.8 \%$ in wild Amaranthus species found in Mexico. The protein content also compares well with the amount found in spinach (approx. 27g/100g), but much higher than that found in cabbage (approx. 15g/100g) (Langenhoven et al., 1991), two vegetables that are widely consumed by the rural population.

Nitrate content in the five accessions is shown in Table 1. There were significant differences $(p<0.05)$ in nitrate content of different accessions of Amaranthus. AMA5 and V2 had the highest levels and AMA18, AMA17 and VOP the lowest. Nitrate values obtained in this study for AMA18, AMA17 and VOP agree with those reported in the literature (Mziray et al., 2001). AMA5 and V2 had high nitrate levels and therefore consumption of these two accessions should be limited so as not to exceed the recommended limit for nitrate. WHO and United Nations

\begin{tabular}{|l|l|l|l|}
\hline \multicolumn{4}{|c|}{$\begin{array}{l}\text { TABLE 1 } \\
\text { vegetable of five Amaranthus accessions (on dry } \\
\text { mass basis) }\end{array}$} \\
\hline $\begin{array}{l}\text { Amaranthus } \\
\text { accession }\end{array}$ & $\begin{array}{l}\text { Vitamin C } \\
\text { mg 100 }^{-1}\end{array}$ & $\begin{array}{l}\text { Protein } \\
\mathbf{g ~ 1 0 0 g}^{-1}\end{array}$ & $\begin{array}{l}\text { Nitrate } \\
\text { mg 100 }^{-1}\end{array}$ \\
\hline AMA 5 & $630.9 \mathrm{a}$ & $29.82 \mathrm{a}$ & $1413 \mathrm{a}$ \\
\hline V2 & $618.9 \mathrm{a}$ & $29.94 \mathrm{a}$ & $1474 \mathrm{a}$ \\
\hline AMA 18 & $522.5 \mathrm{c}$ & $25.79 \mathrm{~b}$ & $790.5 \mathrm{~b}$ \\
\hline AMA 17 & $496.5 \mathrm{c}$ & $31.21 \mathrm{a}$ & $790.9 \mathrm{~b}$ \\
\hline VOP & $569.7 \mathrm{~b}$ & $28.56 \mathrm{ab}$ & $729.3 \mathrm{~b}$ \\
\hline
\end{tabular}

Values in the same column followed by the same letter are not significantly different $(p>0.05)$. 


\begin{tabular}{|l|c|c|c|c|c|c|c|c|}
\hline \multirow{2}{*}{ Mineral concentrations in the vegetable of five Amaranthus accessions (on dry mass basis) } \\
\hline \multirow{2}{*}{ Accession } & \multicolumn{9}{c|}{ Mineral content $\left(\mathbf{m g} \mathbf{1 0 0 \mathbf { g } ^ { - 1 }}\right)$} \\
\cline { 2 - 9 } & $\mathbf{P}$ & $\mathbf{M g}$ & $\mathbf{C a}$ & $\mathbf{M n}$ & $\mathbf{F e}$ & $\mathbf{Z n}$ & $\mathbf{N a}$ & $\mathbf{K}$ \\
\hline AMA 18 & $413.7 \mathrm{ab}$ & $32.95 \mathrm{c}$ & $1287 \mathrm{~b}$ & $8.30 \mathrm{ab}$ & $12.23 \mathrm{~b}$ & $4.21 \mathrm{bc}$ & $32.11 \mathrm{c}$ & $4455 \mathrm{~b}$ \\
\hline V2 & $396.0 \mathrm{~b}$ & $39.56 \mathrm{ab}$ & $1286 \mathrm{~b}$ & $8.24 \mathrm{ab}$ & $13.26 \mathrm{ab}$ & $4.69 \mathrm{ab}$ & $42.71 \mathrm{~b}$ & $4801 \mathrm{a}$ \\
\hline VOP & $426.0 \mathrm{ab}$ & $36.63 \mathrm{bc}$ & $1417 \mathrm{~b}$ & $10.31 \mathrm{a}$ & $14.62 \mathrm{a}$ & $3.99 \mathrm{c}$ & $39.51 \mathrm{~b}$ & $4521 \mathrm{~b}$ \\
\hline AMA 5 & $409.7 \mathrm{~b}$ & $41.26 \mathrm{a}$ & $1756 \mathrm{a}$ & $6.64 \mathrm{~b}$ & $12.83 \mathrm{ab}$ & $4.64 \mathrm{ab}$ & $39.38 \mathrm{~b}$ & $4669 \mathrm{ab}$ \\
\hline AMA 17 & $457.3 \mathrm{a}$ & $42.52 \mathrm{a}$ & $1851 \mathrm{a}$ & $9.18 \mathrm{a}$ & $14.55 \mathrm{ab}$ & $5.03 \mathrm{a}$ & $175.9 \mathrm{a}$ & $4892 \mathrm{a}$ \\
\hline LSD (0.05) & 47.31 & 3.96 & 267 & 2.20 & 2.35 & 0.63 & 7.04 & 249.9 \\
\hline
\end{tabular}

Values in the same column followed by the same letter are not significantly different $(\mathrm{p}>0.05)$.

currently recommend an ADI of nitrate of 0 to $0.07 \mathrm{mg}$ nitrate ion per kg body weight (CSPH, 2005). High levels of nitrate intake can be a problem for individuals suffering from anaemia because of their lower baseline oxygen carrying capacity and therefore making them more susceptible to methaemoglobinaemia (McKnight et al., 1999). Unfortunately in the rural areas anaemia is a problem of public health significance and therefore V2 and AMA5 as vegetables should be used cautiously. On the other hand the two accessions also contained the highest amounts of vitamin C (Table 1). It has been reported that Vitamin $\mathrm{C}$ inhibits the nitrosation of nitrate to produce nitrite and ultimately the nitroso (NO-) compounds which are carcinogenic (Corre and Breimer, 1979). Therefore, methods that conserve vitamin $\mathrm{C}$ should be used when cooking these vegetables.

The mineral content of the vegetables from the different accessions are shown in Table 2. There were significant differences in mineral contents of all the minerals analysed for. AMA17 contained the highest levels of all the minerals, followed by AMA5 and V2. AMA18 was high only in phosphorus and manganese. These results show that Amaranthus vegetable used effectively can assist in meeting the daily recommendations of important nutrients.

From the data obtained above, AMA17 is the best accession to use as vegetable. Besides having the highest amounts of minerals it had the highest protein content and lowest nitrate content. In the green house AMA17 also flowered three weeks after the other accessions had flowered, indicating that vegetable harvesting can continue for a longer period compared to the other accessions.

\section{Nutrient content of seeds}

The crude fat and protein contents of the seed from the five Amaranth accessions are shown in Table 3. V2 contained significantly higher amounts $(\mathrm{p}<0.05)$ of crude fat $(4.82 \%)$ than the others and AMA17 contained the lowest amount (3.53\%).

The protein content varied between 12.96 and $14.97 \%$.

\begin{tabular}{|l|c|c|}
\hline \multicolumn{3}{|c|}{$\begin{array}{c}\text { TABLE 3 } \\
\text { Fat and protein contents of the seeds } \\
\text { of five }\end{array}$} \\
\hline Amaranth accessions
\end{tabular}

*Nd: not determined.

Values in the same column followed by the same letter are not significantly different ( $p>0.05$ ).

AMA18, V2 and VOP had significantly higher values $(p<0.05)$ than the others and AMA5 had the lowest amount. The protein content values obtained in this study are within the range of 12 to 19\% reported in literature (Bressani, 1989). The amount of protein in the seeds is higher than that found in rice (7 to $10 \%$ ) and maize (9 to 10\%) (Centeotl, 2002). The protein has been reported to be high in lysine and sulphur-containing amino acids. Amaranth seed has double the lysine of wheat, triple that of maize and equal to the amount found in milk (Centeotl, 2002), which makes the seeds attractive for use in a blend of foods to increase the biological value of the protein.

The mineral contents in the seeds of the five Amaranth accessions are presented in Table 4 .

Generally the seeds from all accessions were low in sodium and high in potassium (14 to $29 \mathrm{mg} \mathrm{Na} / 100 \mathrm{~g}$ and 470 to $601 \mathrm{mg}$ $\mathrm{K} / 100$ g respectively). AMA17 contained almost three times the amount of manganese found in the other accessions $(23.37 \mathrm{mg}$ compared to 7.58mg in AMA18, $6.90 \mathrm{mg}$ in VOP and $7.8 \mathrm{mg}$ in AMA5). AMA17 also contained the highest amounts of zinc, calcium and sodium. AMA18 and VOP contained the highest amounts of iron and phosphorus. AMA18 contained the high-

\begin{tabular}{|c|c|c|c|c|c|c|c|c|}
\hline \multicolumn{9}{|c|}{$\begin{array}{c}\text { TABLE } 4 \\
\text { Mineral content of the seeds of five } A\end{array}$} \\
\hline \multirow[t]{2}{*}{ Accession } & \multicolumn{8}{|c|}{ Mineral content $\left(\mathrm{mg} 100 \mathrm{~g}^{-1}\right)$} \\
\hline & $\mathbf{P}$ & Mg & $\mathrm{Ca}$ & Mn & $\mathrm{Fe}$ & $\mathrm{Zn}$ & $\mathrm{Na}$ & $\mathrm{K}$ \\
\hline AMA18 & 388.7ab & $8.39 \mathrm{~b}$ & $306.8 \mathrm{~b}$ & $7.58 \mathrm{c}$ & $7.54 a$ & $2.66 \mathrm{c}$ & $19.58 \mathrm{bc}$ & 601.3a \\
\hline V2 & $395.7 \mathrm{a}$ & $9.42 \mathrm{a}$ & $278.8 b c$ & $10.78 \mathrm{~b}$ & $6.80 \mathrm{bc}$ & $2.70 \mathrm{c}$ & 15.98cd & $546.4 \mathrm{~b}$ \\
\hline VOP & 389.7ab & $6.19 c$ & $160.2 \mathrm{~d}$ & 6.90c & 7.29ab & $3.76 \mathrm{~b}$ & $14.21 \mathrm{~d}$ & $500.6 \mathrm{c}$ \\
\hline AMA5 & $381.3 \mathrm{~b}$ & 9.59a & $272.4 \mathrm{c}$ & $7.8 \mathrm{c}$ & $6.75 b c$ & $3.15 b c$ & $22.43 b$ & $520.5 b c$ \\
\hline AMA17 & $345.3 c$ & $8.55 \mathrm{~b}$ & $370.1 \mathrm{a}$ & $23.37 a$ & $6.51 \mathrm{c}$ & 4.86a & $29.45 a$ & $470.7 d$ \\
\hline LSD (0.05) & 11.97 & 0.38 & 29.53 & 2.67 & 0.58 & 0.70 & 4.66 & 29.49 \\
\hline
\end{tabular}

Values in the same column followed by the same letter are not significantly different ( $p>0.05)$. 
est amount of potassium. V2 was rich in phosphorus and magnesium. The mineral values obtained in Amaranthus seeds are similar to the values reported for calcium, iron and potassium by Centeotl (2002).

In terms of using Amaranthus seeds for fortifying food, the accession to be used would depend on the nutrient of interest. In this regard the high manganese and zinc levels found in the seed of AMA17 are of particular interest. In some areas in the former Transkei region of the Eastern Cape the incidence of oesophageal cancer is amongst the highest in the world, whereas in other parts of the Transkei the incidence is much lower. Research in the Department of Soil Science at the University of Fort Hare has found strong indications that the high incidence areas are characterised by low dietary manganese levels in the staple food of the people in the high incidence areas (Laker et al., 1983; Deckers et al., 2000). Indications of relationships between low manganese availability and high cancer incidence have also been found elsewhere in the world (Deckers et al., 2000). Likewise the high zinc content of AMA17 seed may perhaps be of special interest in view of the importance of adequate zinc in the human diet. One of the most important roles of zinc in human nutrition is to maintain the body's immune system (Nauss and Newberne, 1982; Oliver, 1997). The effects of zinc deficiency in this regard are 'profound', rendering the zinc-deficient person extremely vulnerable to a whole range of infections (Nauss and Newberne, 1982).

\section{Conclusion}

Amaranthus accessions found in the Eastern Cape are rich in protein, minerals and vitamin C. Two accessions (AMA18 and V2) contained high levels of nitrates and therefore consumption as vegetable should be done cautiously. AMA17 was best suited for vegetable consumption since it had the highest amounts of minerals and protein and lowest nitrate content. AMA17 seeds also contained high amounts of protein and minerals, which make them suitable for improving the quality of rural diets. Further research is now necessary to create awareness of the nutritional value of Amaranthus in rural areas and to include it in their gardens. In addition training on how to utilise the vegetable and the grain is necessary.

\section{References}

ALLEMANN J, VAN DER HEEVER E and VILJOEN A. (1996) Evaluation of Amaranthus as a possible vegetable crop. Appl. Plant Sci. 10 1-4

ALETOR VA and ADEOGUN OA (1995) Nutrient and anti-nutrient components of some tropical leafy vegetables. Food Chem. 53 375379.

BRESSANI R (1989) The protein of grain amaranth. Food Rev. Int. 5 13-38.

CENTEOTL (2002) Amaranth: Ancient food of the gods for the people of today. Nutritional value. [Online]. Available at: http://prodigyweb.net.mx/centeotlac/eng/pages/valor.htm (Accessed on 5/ 4/ 2006).

CORRE WJ and BREIMER T (1979) Nitrate and Nitrite in Vegetables. Wageningen Pudoc. Centre for Agricultural Publishing and Documentation. Wageningen, The Netherlands.

COUNCIL ON SCIENCE and PUBLIC HEALTH (CSPH) (2005) Report No. 9. [Online] Available: <http://www.ama-assn.org/ama/ pub/category/1366.html> (Accessed on 15/05/2006).

DECKERS J, LAKER M, VANHERREWEGHE S, VANCLOOSTER M, SWENNEN R and CAPPUYNS V (2000) State of the art on soilrelated geo-medical issues in the world. In: Lag J (ed.) Geomedical Problems in Developing Countries. Norwegian Academy of Science and Letters, Oslo. 23-42.
DHELLOT JR, MATOUBA MG, MALOUMBI JM, NZIKOU DG, LINDER M, DESOBRY S and PARMENTIER M (2006) Extraction, chemical composition and nutritional characterization of vegetable oils: Case of Amaranthus hybridus (var 1 and 2) of Congo Brazzaville. African J. Biotech. 5 1095-1101.

FAO (1995) Fruits and vegetable processing. FAO Agricultural Services Bulletin 1:119 Food and Agricultural Organization of the United Nations, Rome Italy.

FAO/WHO (2004) African Leafy Vegetables: Their roles in the World Health Organization's Global Fruit and vegetable Initiative. [Online] Available at: $<$ http://www.ipgrii.cgiar.org/Events/nutrition/Related. html $>$ (Accessed on 23/05/2006).

FREED R, EISENSMITH SP, GOETZ S, REICOSKY D, SMAIL VM and WOLLBERG P (1990) MSTAT-C A Microcomputer Program for the Design, Management and Analysis of Agronomic Research Experiments Michigan State University.

GRIJSPAARDT-VINK (1994) A European view of nitrates in vegetables. European Report . J. Food Tech. for the Netherlands and Belgium July 1994. $31 \mathrm{pp}$.

GUILLET D (2004) Grain Amaranthus, History and Nutrition. Kokopelli Seed Foundation [Online] $\leq$ http://www.kokopelli-seed-foundation.com/amaranths.htm $>$ (Accessed on 10/4/2006).

INTERNATIONAL INSTITUTE OF TROPICAL AGRICULTURE (IITA) (1979) Colorimetric determination of nitrate in plant tissue. In: Selected Methods for Soil and Plant Analysis. Ibadan, Nigeria. $55 \mathrm{pp}$.

LAKER MC, BEYERS CPdeL, VAN RENSBURG SJ and HENSLEY M (1983) Environmental associations with oesophageal cancer: An integrated model. Proc. $10^{\text {th }}$ Natl. Congr. Soil Sci. Soc. S. Afr. July 1981, East London, South Africa. Techn. Commun. No. 180, Dept. Agric. 81-90.

LANGENHOVEN ML, KRUGER M, GOUWS E and FABER M (1991) MRC Food Composition Tables Second edition. [Online] Available at: $\leq$ http://www.mrc.ac.za/servlets/FoodCompResp $>$ (Accessed 10/05/2006).

MATHOOKO FM and IMUNGI JK (1994) Ascorbic acid change in three indigenous Kenyan leaf vegetables during traditional cooking Ecol. of Food and Nutr. 32 239-245.

McKNIGHT GM, DUNCAN CW, LEIFERT C and GOLDEN MH (1999). Dietary nitrate in man: friend or foe? Br. J. Nutr. 81 349358.

MIRVISH SS (1983) The etiology of gastric cancer: Intra-gastric nitrosamide formation and other theories J. Natl. Cancer Inst. 71631.

MORALES E, LEMBECKE J and GRAHAM GG (1988) Nutritional value grain amaranth and maize-amaranth mixtures for children. J. Nutr. 118 78-85.

MZIRAY RS, IMUNGI JK and KARURI EG (2001) Nutrient and antinutrient contents of raw and cooked Amaranthus hybridus. Ecol. of Food and Nutr. 40 53-65.

NAUSS KM and NEWBERNE PM (1982) Trace elements and immunocompetence. In: Gawthorne JM, Howell JMC and White CL (eds.) Trace Element Metabolism in Man and Animals. Springer-Verlag, Berlin. 603-612.

OLIVER MA (1997) Soil and human health: A review. Eur. J. Soil Sci. 48 573-592.

OKALEBO JR, GATHUA KW and WOOMER PL (2002) Laboratory Methods for Soil and Plant Analysis: A Working Manual ( $2^{\text {nd }}$ edn.). Tropical Soil Fertility and Biology Program Nairobi, Kenya.

OLIVEIRA JS and DE CARVALLO MF (1975) Nutritional value of some edible leaves used in Mozambique. Econ. Bot. 29255.

PETER PW AND NGWANDLA XJ (2001) Domestication of Indigenous Plants ARDRINEWS- Agricultural and Rural Development Research Institute- Newsletter - University of Fort Hare July 2001. 2 pp.

TOMOHIRO S (1990) Determination of Vitamin C (ascorbic acid) by indophenol method. In: Laboratory Manual for Food Analysis. Jomo Kenyata University College of Agriculture and Technology, Kenya. 49 pp.

WESCHE-EBELING P, MAITI R, GARCIA-DIAZ G, GONZALES DI and AOSA-ALVARADO F (1995) Contributions to the botany and nutritional value of some wild Amaranthus species (Amaranthaceae) of Nuevo Leon, Mexico. Econ. Bot. 49 423- 430. 